\title{
清水建設株式会社研究所（研究所紹介・その 2)
}

\author{
正会員近藤芳 美*
}

清水建設株式会社研究所が最初に発足したのは戦時中 の昭和 19 年, 建設業界の研究機関としては最も古い歴 史を持っているものの一つである。はじめは設計部門の 一七クションとして, 研究課といろ名のもと飞生れ, 主 として当時の代用資材の研究, 扰よび地下工場の計画等 の研究を担当した。以来, 研究室, 研究部, 研究所とス タッフ扮よび試験機器を充実させながら今日に至ってい る。その間, 工場生産住宅の実施を手がけたり, $\mathrm{AE} コ$ ンクリートの導入，ス、イディングフォームの開発，基 礎工法の改良等の研究を行なって来た。現在の研究所 は, 機構上は社内のスタフ部門の一組織として運営さ れ, 次の各研究部課に分れている。

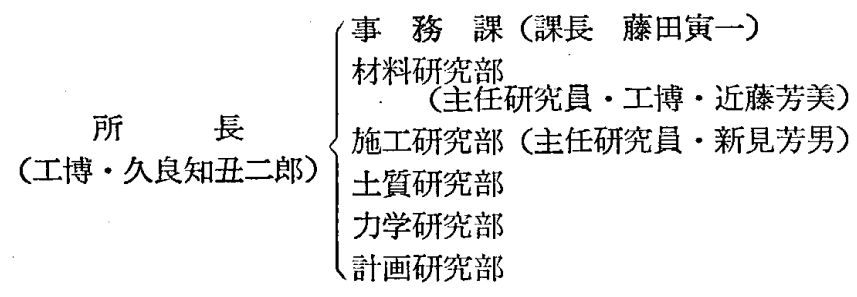

研究所員数は 38 名 (昭和 37 年 4 月現在), 他の産 業の研究部門に比較すれば恥しいほどと小規模なもので はあるが，一応各専門分野にわたった研究要員も配置さ れているし, 建築以外の研究技術者も, 逐次允実されつ つある現状である。

研究所の所在地は東京都中央区宝町二丁目, 清水建設 本社の建物内であり，その6 階と地階とに次の各室にわ かれて配置されている。

$$
\left\{\begin{array}{l}
6 \text { 階 }\left\{\begin{array}{l}
\text { 所長室, 事務室, 各研究室 } \\
\text { 計画実験室 } \\
\text { 構造施工実験室 } \\
\text { 材料実験室 } \\
\text { 化学分析室 } \\
\text { 図 書 室 }
\end{array}\right. \\
\text { 地 階 }\left\{\begin{array}{l}
\text { 強度試験室 } \\
\text { コンクリート養生室 } \\
\text { 恒温恒湿室 } \\
\text { 土質試験室・その他 }
\end{array}\right.
\end{array}\right.
$$

各試験室飞設置されている主な試験機器は200 屯万能 試験機（電子管平衡式）をはじめ，30屯，5屯の各試験 機, $500 \mathrm{~kg}$ 引張試験機, ウェザメーター等で, その他 そ, 一応セメント, コンクリート等の材料武験, あるい は土質試験等の規定の試験の出来るだけの設備は整備さ れて来ている。地下の強度試験室に, 本館と別個の空気 調整施設がなされ，コンクリート混練の場合等を考慮し

* 清水建設技術研究所主任研究員 - 工博
て吸栕装置も用意されている点など，いくらか見党ない 個所にも新しい串験室としての注意が払われてはいる。

このようと, 本社の建物内部に研究所の諸設備胥配置 したことは, 建設工業のような企業の性質にとって, 現 場之研究所の有機的な連絡の目的のため飞は大变飞有利 であり，研究所が非常に便利がられて利用される事にも なっているのではあるが，一面面積上の制約があり，

業務の増加と共に困った問題ともなって来ている。現在 は越中島に屋外実験場を別に使用している。

研究所員の業務は純粋な研究と共に工事現場, 設計部 閇等から依頼されて行なう試験, むるいは現場指導に類 するものがふくまれて括り, 現状は, むしろ後者の場合 が多く, 所員の一人一人がそのために少なから双時間を さかなければならない状龍である。このよろな，現場あ るいは設計に対する技術的 Consultation の業務は, 吾 々の上ろな企業体の中の研究所飞要請される止むを得な い真担部分だと現段階では高わなければならない。同時 飞, そうした次々飞持ちこまれる,Consultation の中に， 吾々企業体の中の研究者の, 当面の研究課題がふくまれ ているのだとも考えなければならない。との意味で，依 頼される教験とか調查とか, 事故の後処理の上うな仕事 も, 或る㖏味では必要な研究業務の一部とも考兄て行な っている。

そうした日常的な業務以外の研究は, 研究員の备自の 自主的なテーマと，会社から命令されるテーマと従っ て行なう事となっている。実際には削者の場合が多く, この場合は，各会計年度のはじめに，一応所員全員によ る研究打合せ会をひらきその席でテーマの適否を討論 検討すると共に, 原則として每月 1 回, 同じ打合せ会で 進行状況を報告し, 相互飞批判を行なう事ともなってい る。

現在行なっている研究には, 主として次のようなテー マのものがある。

\section{A. 材料研究部 :}
1）コンクリート熏裂防止の研究
2）コンクリート急速養生の研究
3）型態によるコンクリートの基礎的性質の研究
4) 材料接着性向上の研究
5）床タイル施工方法の基礎的研究
6）人工軽量骨材の研究・その他

\section{B. 施工研究部 :}

1）建築工場生産化の研究

2) 柱礎工法の研究

3）型枠改良と組立方法の研究 
4）重コンクリートの研究

5）プレパクトグラウトの研究

6）簡易バッチャプラントの開発研究・その他

\section{C. 土質研究部 :}

1）液性限界簡易測定法の研究

2）標準貫入試験の深さの影響の研究

3）杭の水平抵抗関卞る研究

4）建物沈下の実測研究 - その他

D. 力学研究部 :

1) 杭打応力の動力学的解析の研究

2) 建物固有周期の研究

3）鋼管パイルの設計と施工法の研究

4）山留土生応力の測定研究

5）高張力ボルトの施工規準の研究

6）電子計算機による構造物設計法の研究・その他

E. 計画研究部 :
1）設計図の記号化の研究
2) 動線計画の数学的解析の研究
3）公立小学校のブロックのプランの解析研究
4) 日射による熱取得・熱放散の研究
5）分岐ダクトの調和空気分配の研究
6）事務空騒音の研究・その他

企業体の中に和ける研究所の性格として, 去の研究の

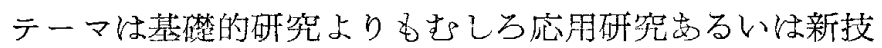
術の開発研究に重心が和かれなければならない事は当然 であるが，現状はかならずしるそうではなく，前揭のテ 一マの如さかなり基礎的なものも取り上げられている。 このようなテーマを各研究部門で取り上げなければなら ない理由は日常試験あるいは現場に齐するConsultation を通して，こうした間題が当然に必要な研究課題として 各自に集約されて来るため飞他ならない。

新技術の開発己いった日立らやすい成果学追わず，地 味な, 建築技術の後進性自体の中に残されている技術的 盲点の解明, 解決をテーマとして行くということが, 当
面の吾々の研究業務だという風に考えている。このこ とは建設企業体の中の研究部門の, 現段階に打ける共通 の宿命であり，宿題であるとる言えよう。

このようにして行なわれる研究の成果は, “技術宝” といら部門を通して実施現場に流されると共に, “研究 所報”としても発表さるる事になっている。“侀究所

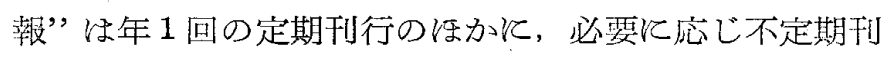
行更予定されている。

建設会社の上うな企業体に拾いて, 研究所の性格柱他 の産業任どに单純明快ではなく, 純粋の研究ということ ばには包括し得ない, 材料試験とか, 現場武験とか事故 処理などの業務がかなりの部分を占めて来る类状はすで に記した通りではあるが，一面に，そのために絶えず実 祭の工事現場との接触が保たれている事にもなり，現笑 の中に研究の方向索見出乙得る有利な立場もあるわけで ある。ただ，他の同業会社の場合も同様だとは思うが， 研究所の歴史がいずれる浅く，研究者の層がまだ溥い上 いう事实之共に, 研究所の運営管理にる画然とした方式 が見出されていないという共通のなやみがある䇺であ る。企業体自身が, 自らの企業体の中の研究所の存在を どの程度に理解し, 評価し, 利用しているかという問題 そついても同様である。

しかし，ころした問題, 乃至矛盾にも関らず研究部門 というものは近代企業体としての建設会社の中無くて はすをされない类状となって来ている。建築工学の進步 と共以分化されて行く専門分野の技術を，従来の上うな 建築家あるいは現場技術者の一通りの知識とか経験だけ で処理して行くことは出来なくなって来ているし，その 各分野に次々次知の, 未解決の間題がはら委れて来て いるのでめる。

\section{ニュース欄}

○日本学術会議では第 33 回総会に於て「科学技術に関する基 本法の制定」について8項目にわたる勧告を政府あてに行 い,ついてその内容を検討する委員会を設置したが，3月 10 日 13 時より同会講堂で一般公聴会を催した。

○「学問・思想の自由について」のシンポジュム（第 4 回）を 3 月 29 日 13 時より日本学術会議学問・思想の 自由委員会 主催で催した。

○東洋レーヨン科学技術賞決定 3 月 26 日, 日本工業 クラブ において受賞式究催した。本年度の受賞者は次の通りであつ た。

補乳動物および人類の染色体研究 牧野佐二郎氏（日本遺伝 学会推蔦, 理博北大教授)

酲酵法による諸種アミノ酸の製造に関する研究 加藤 弁三郎 氏（日本農芸化学会推萀, 協和醗酵 K.K. 社長 工博)

第 8 回大河内賞贈賞式泣 4 月 9 日（月）ホテル 国際観光 で催 された。

○1962 1963 年度の建築関係国際会議は次の通り開催される 予定である。

\begin{tabular}{|c|c|c|c|c|}
\hline 会 & 開 & 催 & 地 & 洔 \\
\hline 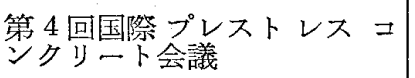 & ナ & ポ & ע & $\begin{array}{l}1962 . \\
5.27 \sim 6.2\end{array}$ \\
\hline $\begin{array}{l}\text { RILEM 焼成粘土の試験研 } \\
\text { 究シンボニウム }\end{array}$ & ร & ラ & ) & $6.25 \sim 6.28$ \\
\hline 国際溶接会議年次大会 & オ & ス & $F$ & $6.26 \sim 6.30$ \\
\hline $\begin{array}{l}\text { 豊面構造 (员屋根，金属骨組 } \\
\text { 国際会議 }\end{array}$ & パ & & リ & 7. $9 \sim 7.11$ \\
\hline 南極設営シンポジユウム & 米 & & 国 & 8. \\
\hline $\begin{array}{l}\text { 第 } 4 \text { 回国際住宅都市計画連盟 } \\
\text { 会議 }\end{array}$ & டீ & & リ & $9.2 \sim 9.9$ \\
\hline $\begin{array}{l}\text { ISO/TC } 92 \text { 建築材料防火試 } \\
\text { 験法 }\end{array}$ & パ & & リ & 9. \\
\hline RILEM 第 16 回会議 & \multirow{2}{*}{\multicolumn{3}{|c|}{$\begin{array}{c}\text { チニーリツヒ } \\
\text { サンフランシスコ }\end{array}$}} & $9.16 \sim 9.19$ \\
\hline 国際シエル構造会議 & & & & 10. $1 \sim 10.4$ \\
\hline ISO/TC 99 建築構造 & \multirow{2}{*}{\multicolumn{3}{|c|}{$\begin{array}{l}\text { パ リルシ } \\
\text { ワルャワー }\end{array}$}} & \multirow{2}{*}{$\begin{array}{l}1963,1 . \\
9.18 \sim 9.21\end{array}$} \\
\hline 第 2 回非線型振動 & & & & \\
\hline $\begin{array}{l}\text { ISO/TC } 99 \\
\text { Semi Manufactures of } \\
\text { Timber }\end{array}$ & \multicolumn{3}{|c|}{$\begin{array}{l}\text { Buearest } \\
\text { (Rumania) }\end{array}$} & $5.29 \sim 6.1$ \\
\hline
\end{tabular}

